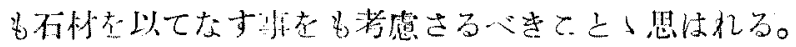

\title{
VI 䋟掘
}

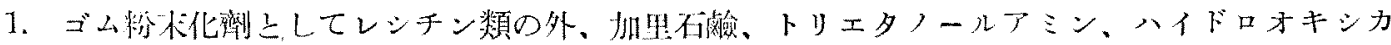

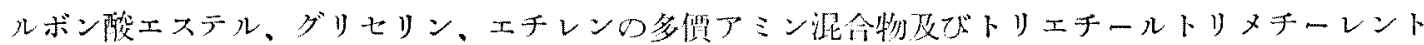

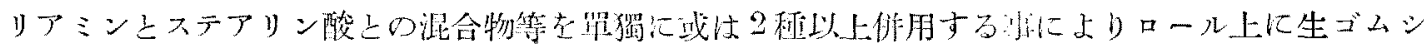

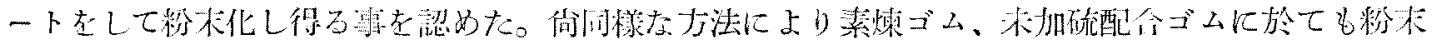

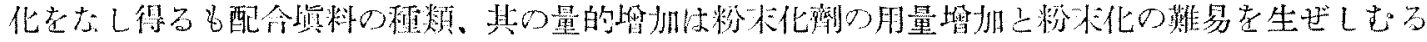
慗考涊的た。

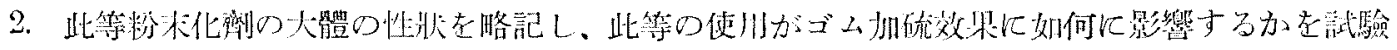

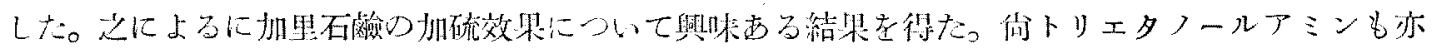

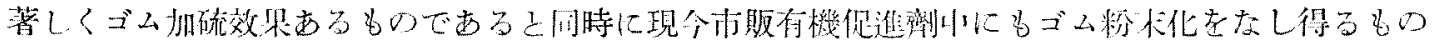
あるを洒りた。

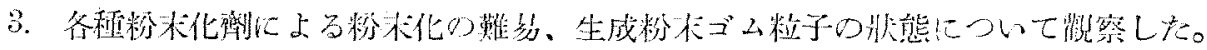

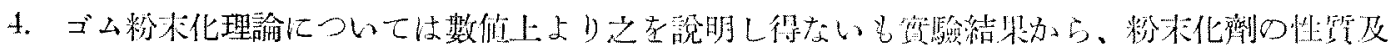
ロール操作による物理的結果によるもの上洘察假定した。

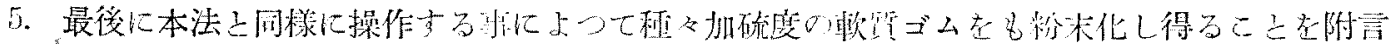
$す る 。$

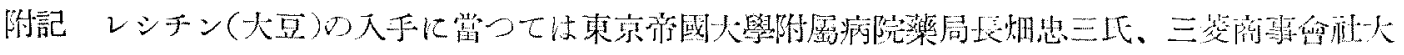

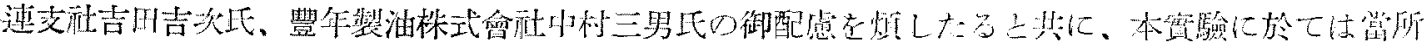

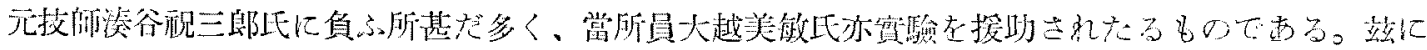

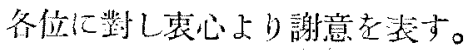

\section{ゴム粉末化と其の利用に關方当研究（第3 壀)

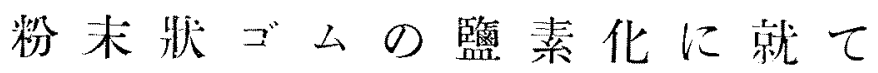

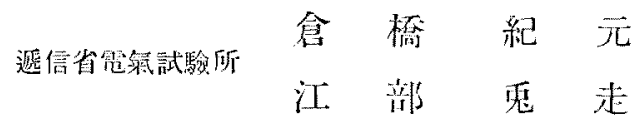

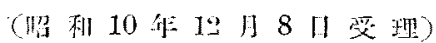

I 絈 言

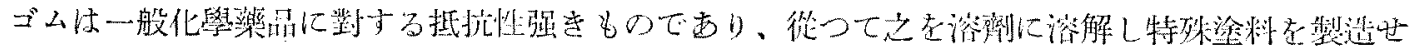




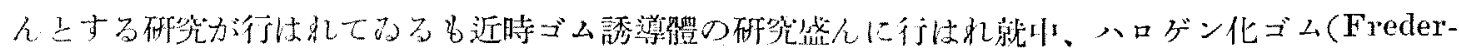

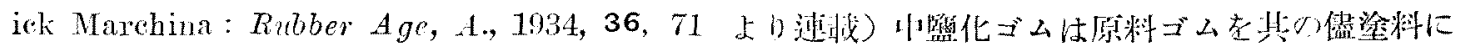

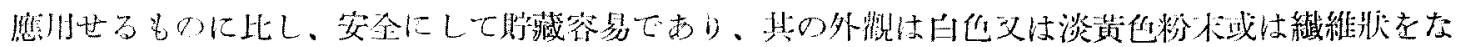

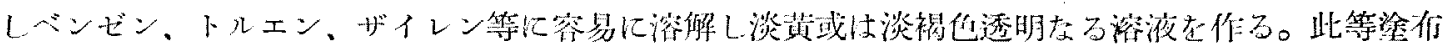

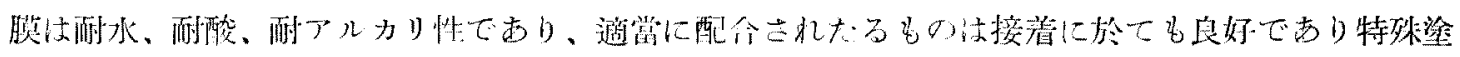

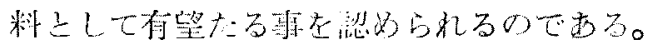

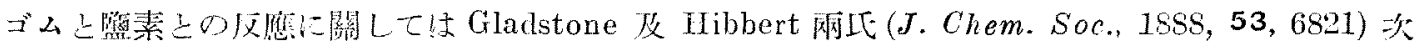
いで ITinrichsen, Quensel u. Kindscher 代 (Ber., 1913, 46, 1283) MacGarack IE (Gummi.Ztg.,

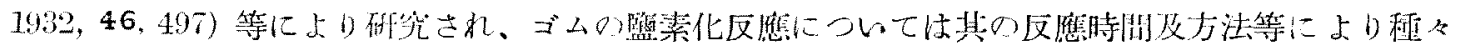

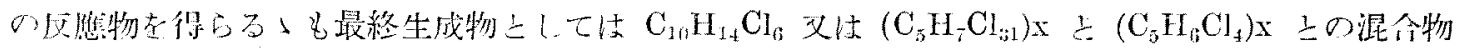
に析當する上云は机てるる。

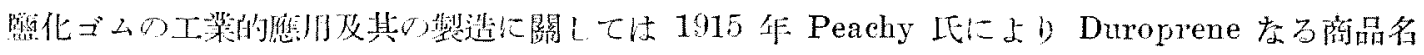

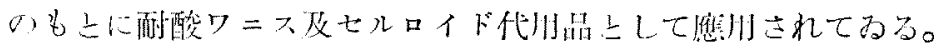

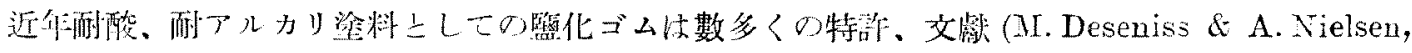
B. P. 328,818; I. G. Farb. Ind. A.-G., B. P. 381,098; India Rubber W., 1931, Oct., 87; 1932,

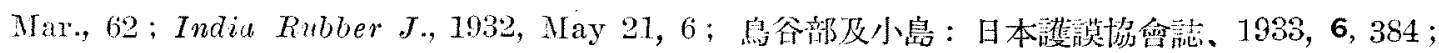

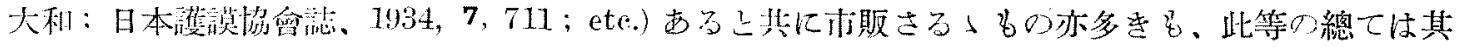

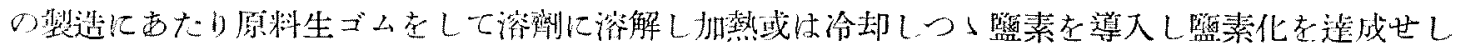

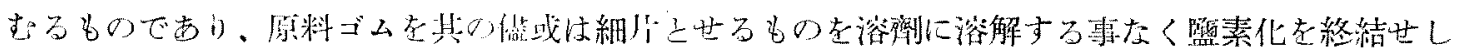

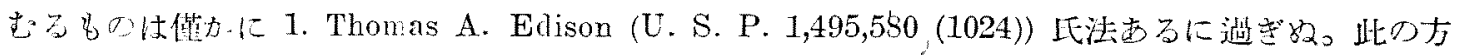

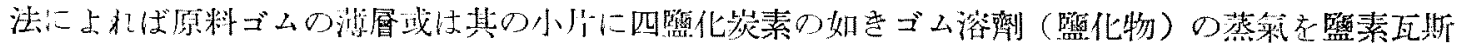

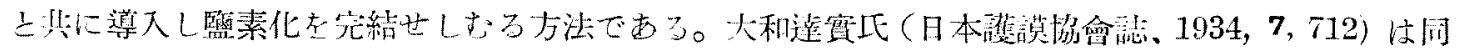

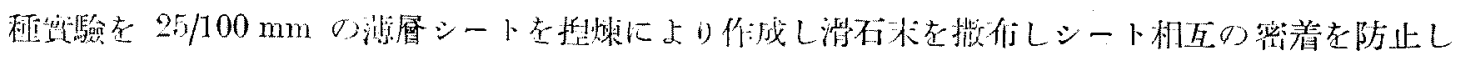

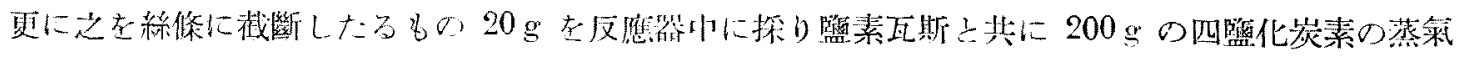

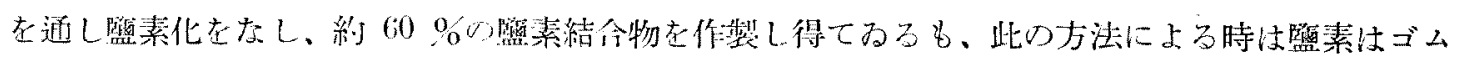

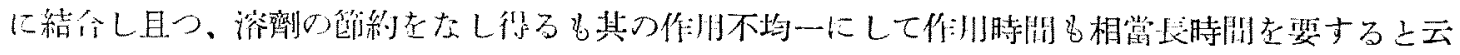
つっる。

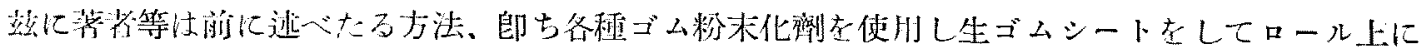

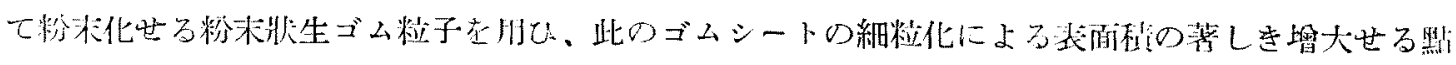

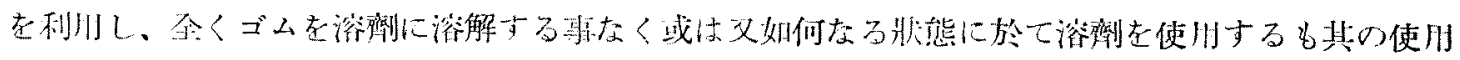

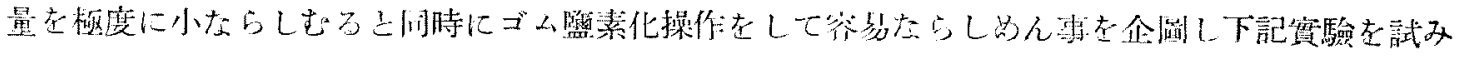
たのであう。 


\section{II 促 歌}

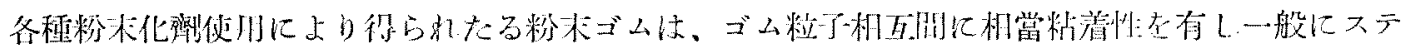

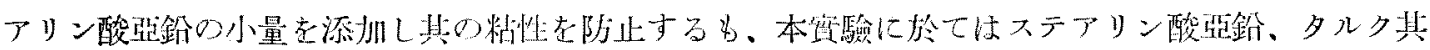

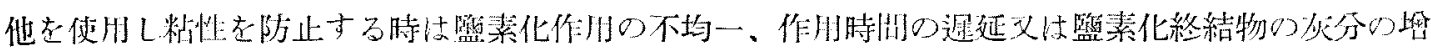

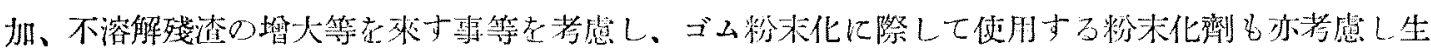

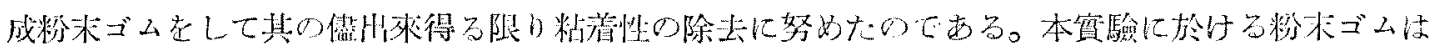

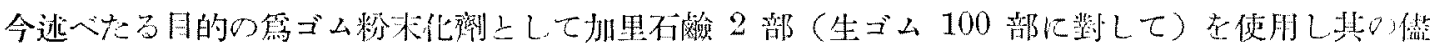

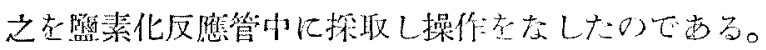

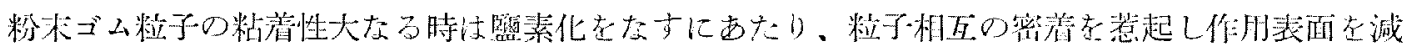

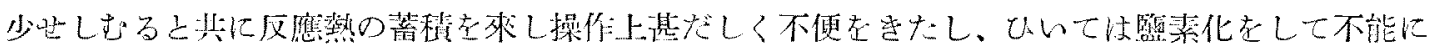
陷らしもるに至る。

\section{$A$ 装置}

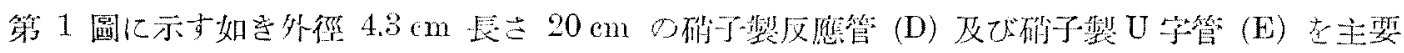

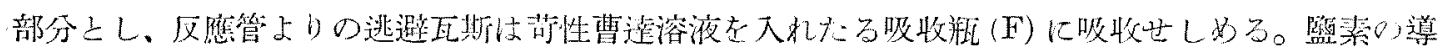

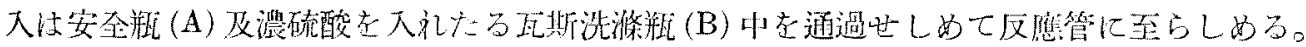

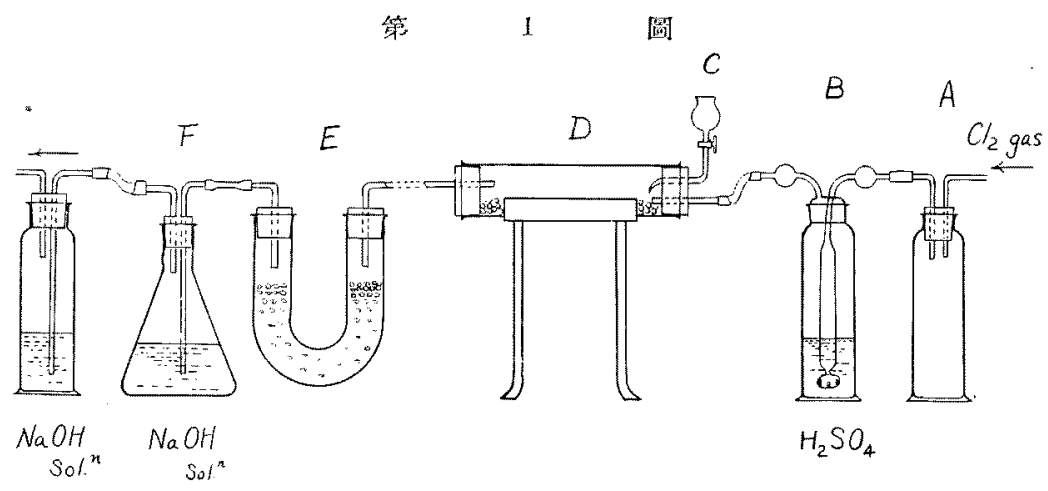

\section{B 豫 满 䮦}

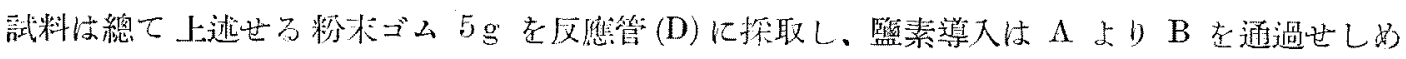
導入正斯の速度は硫酸山在通過する發泡數在もつて調節し反應の初期に於ては 1 尔閏約 100 200

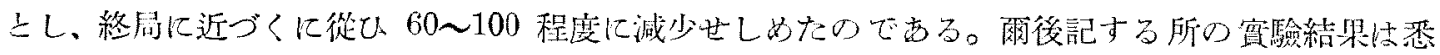

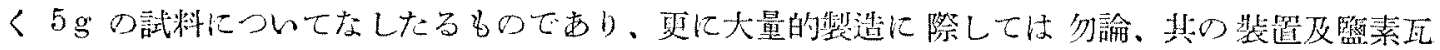
斯導入等に關しては相當の考虑を必要之すべきでする。

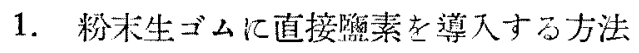

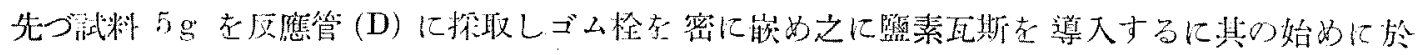




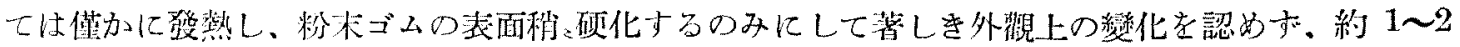

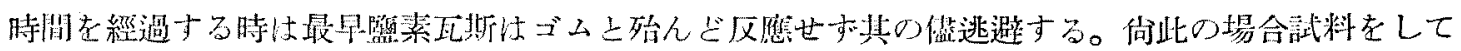

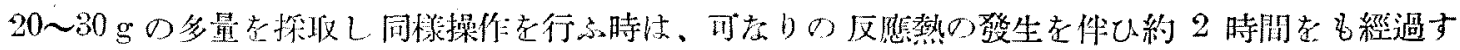

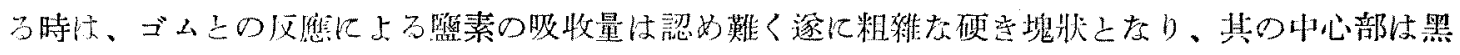
化在虽子。

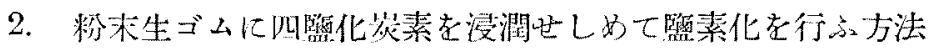

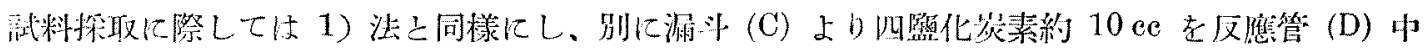

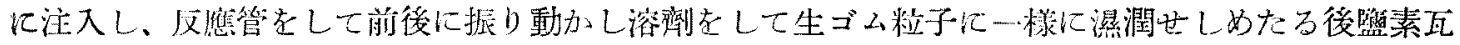

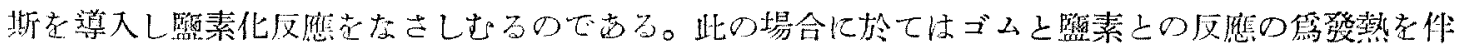

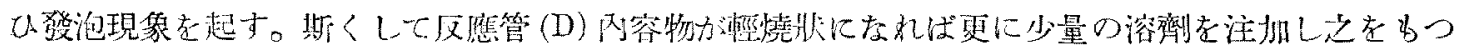

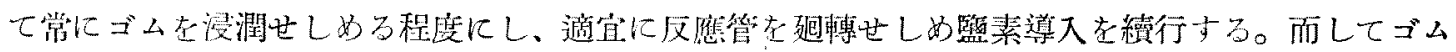

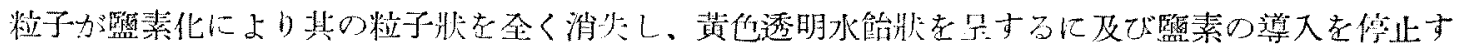
20

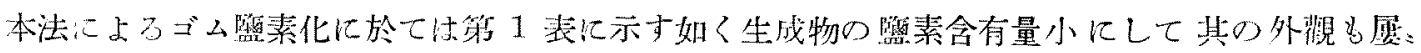

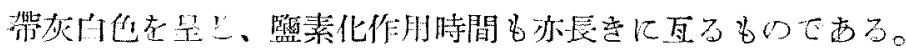

第 1 表

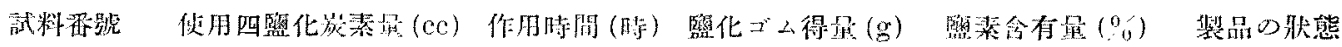

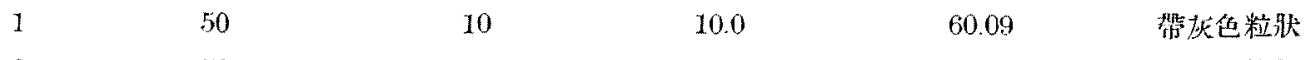

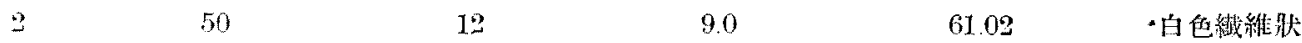

(試料仕 $5 \mathrm{~g}$ 㧺取)

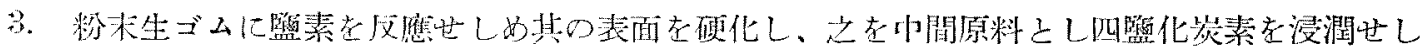

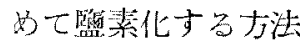

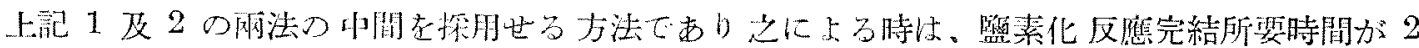

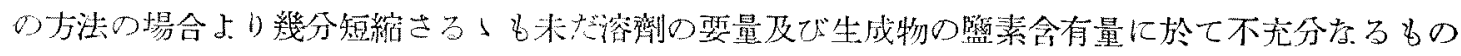
こある。

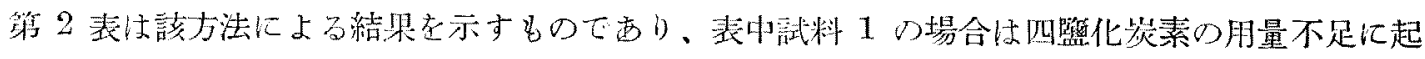

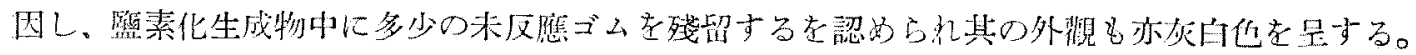

\begin{tabular}{|c|c|c|c|c|c|}
\hline 試料果號 & 四㠊化岁瑟量 (ce) & 作用時閂 (時) & 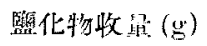 & 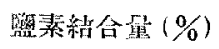 & 裴品の舣熊 \\
\hline 1 & 30 & 5 & 10.5 & 60.59 & 灰白色粗粒 \\
\hline 2 & 50 & 7 & 10.0 & 62.56 & 白色䋊維槑 \\
\hline
\end{tabular}

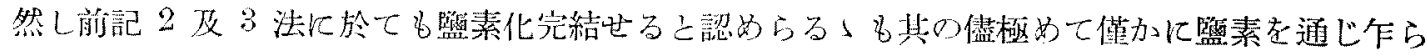

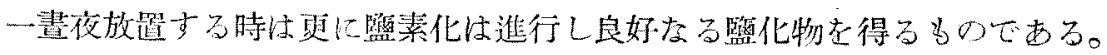

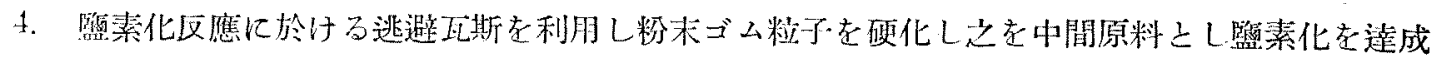




\section{する方法}

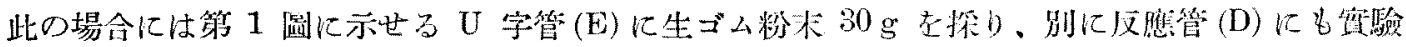

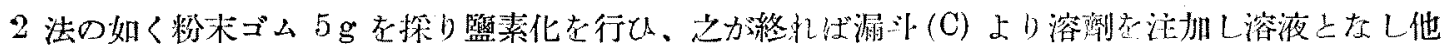

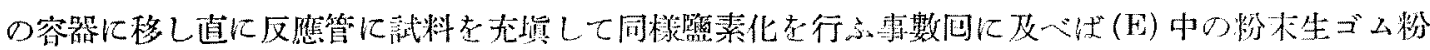

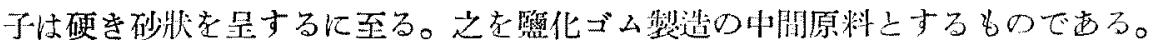

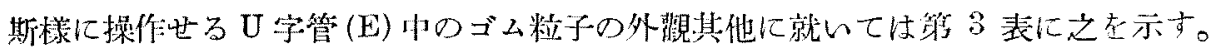

第 3 表

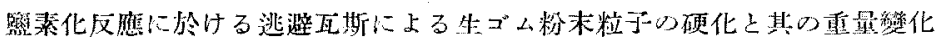

\begin{tabular}{|c|c|c|c|}
\hline 試料(生ゴム粉末)特取曻 (g) & 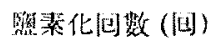 & 硬化ゴん粒于の最（g） & 観 \\
\hline 30 & 1 & 37 & 淡褐他秒：硬化 \\
\hline 30 & 2 & 39 & " 砂狀程 = 硬 L \\
\hline 30 & 3 & 49 & 炏襡色砂射硬 L \\
\hline 30 & 4 & 45 & $"$ \\
\hline 30 & 5 & 47 & $"$ \\
\hline
\end{tabular}

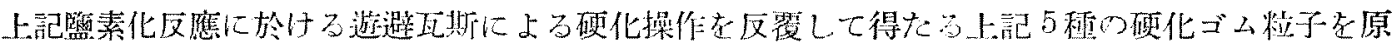

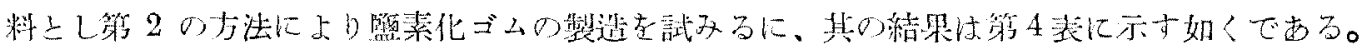

$$
\begin{aligned}
& \text { 第 } 4 \text { 発 }
\end{aligned}
$$

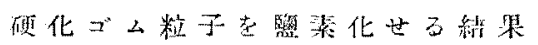

\begin{tabular}{|c|c|c|c|c|c|}
\hline 撨㨞化 & c座肃 & 作用 & 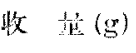 & 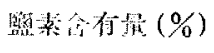 & 㢣品以状態 \\
\hline 1 & 50 & 6.0 & 11.0 & 62.56 & 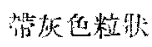 \\
\hline 2 & 40 & 5.0 & 10.5 & 63.06 & 白色粒状 \\
\hline 3 & 30 & 3.0 & 10.0 & 64.62 & 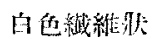 \\
\hline 4 & 80 & 3.0 & 9.5 & 64.29 & "z \\
\hline 5 & 80 & 2.5 & 10.0 & 64.69 & " \\
\hline
\end{tabular}

(武料 $5 \mathrm{~g}$ 探取)

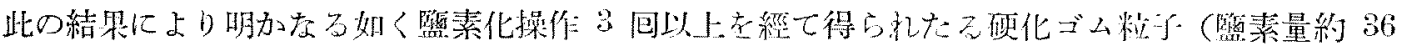

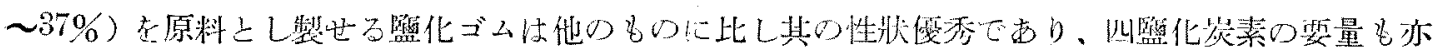

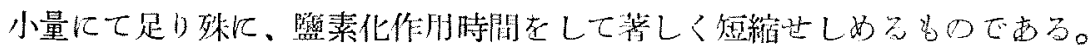

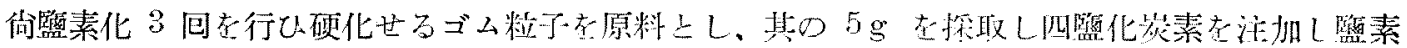

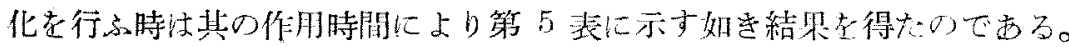

$$
\text { 第 } 5 \text { 表 }
$$

\begin{tabular}{|c|c|c|c|c|c|c|}
\hline 試粼番䟚 & 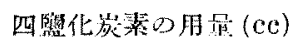 & 作打时成（時） & 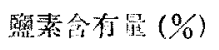 & 收 & 量 $(\mathrm{g})$ & 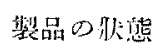 \\
\hline 1 & 80 & 2.5 & 64.62 & 11.0 & & 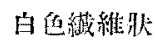 \\
\hline 9 & 30 & 3.0 & 65.29 & 11.5 & & $" z$ \\
\hline 3 & 30 & 9.5 & 65.08 & 11.0 & & $\not t$ \\
\hline
\end{tabular}

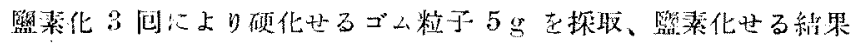

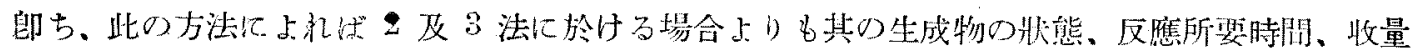




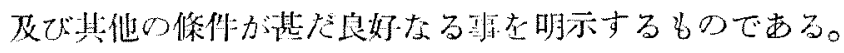

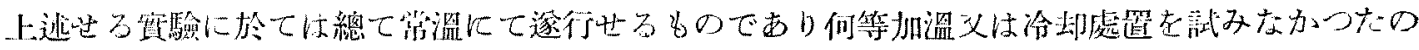

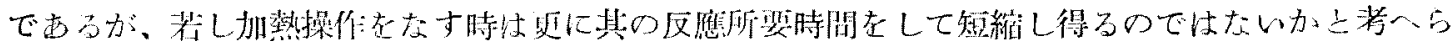

第 6 表

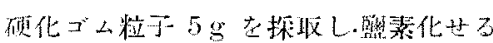

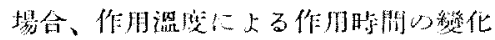

\begin{tabular}{|c|c|c|}
\hline 試料准㩆 & 作用泜度 ${ }^{\circ} \mathrm{C}$ & 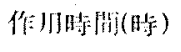 \\
\hline 1 & 25 & 30 \\
\hline 2 & 50 & 8.5 \\
\hline 3 & 80 & 30 \\
\hline
\end{tabular}

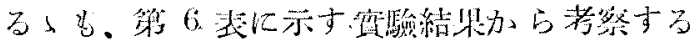

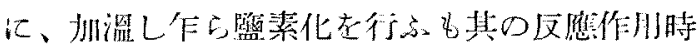

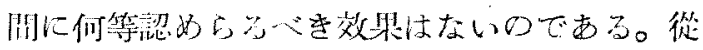
つて斯标な方法に上る監素化操作法赖々の黑加 ら労温にて操价する孝可上すべきである。

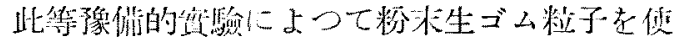

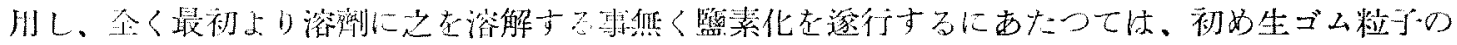

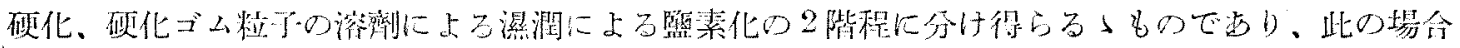

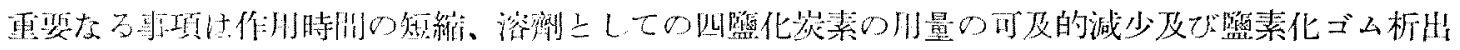

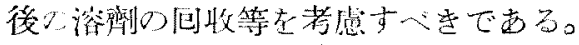

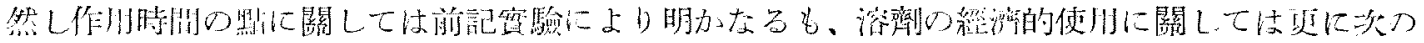

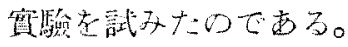

a. 叫整化荻等の川量

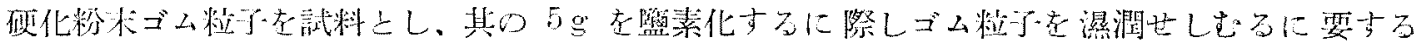

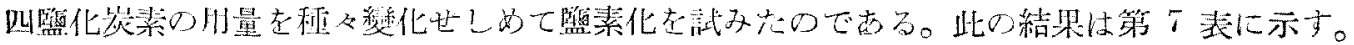

第 7 表

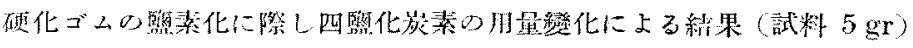

\begin{tabular}{|c|c|c|c|c|}
\hline 試料桖啹 & 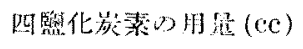 & 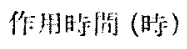 & 整素全疗量: (\%) & 製品の狀態 \\
\hline 1 & 10 & 1 & 54.40 & 灰白色、ゴムそ混ず \\
\hline 2 & 30 & 2 & 56.63 & 灰白色、僅かにダムを混ず \\
\hline 3 & 80 & 3 & 64.30 & 白危、㵶維贆 \\
\hline 4 & 40 & 3 & 63.80 & $" 1$ \\
\hline 5 & 50 & 3 & 64.05 & " \\
\hline
\end{tabular}

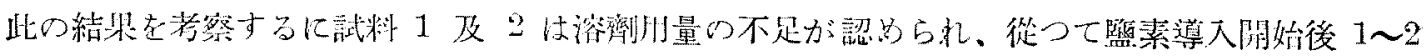

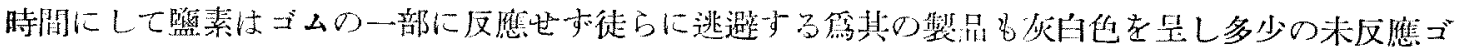

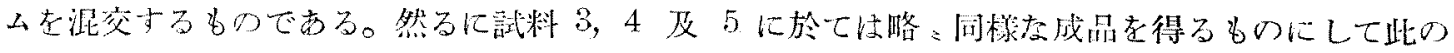

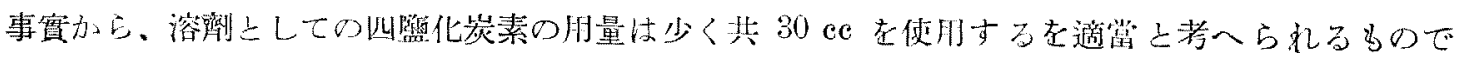
ある

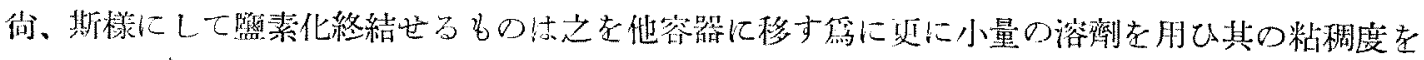

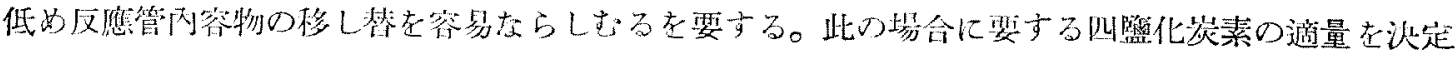

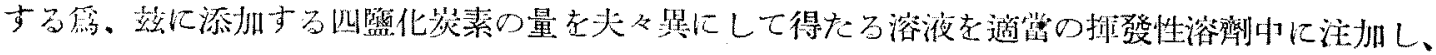




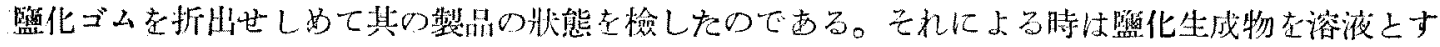

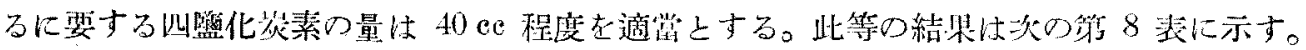

第 8 表

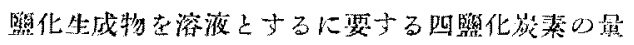

\begin{tabular}{|c|c|c|c|}
\hline 試料番號 & 四學化嵌溱心月量 $(\mathrm{ce})$ & 篮素会有量 $(\%)$ & 析出せる製品心外觀 \\
\hline 1 & 30 & 59.35 & 租惡にしてゴム样物澌を混入す \\
\hline 2 & 40 & 64.29 & 白色䋐維詼 \\
\hline 3 & 50 & 63.80 & $"$ \\
\hline
\end{tabular}

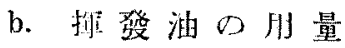

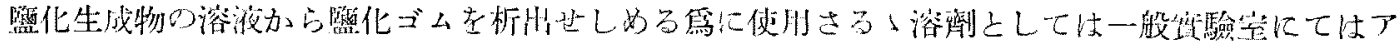

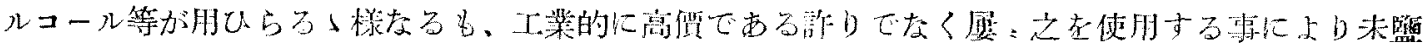
化ゴム在混交せしむる惧がある。

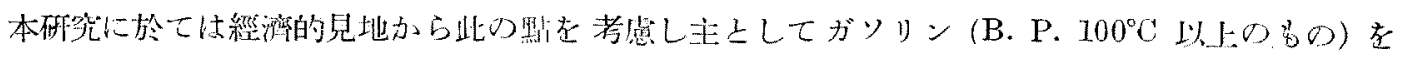
州ひたのである。

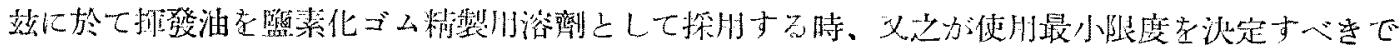

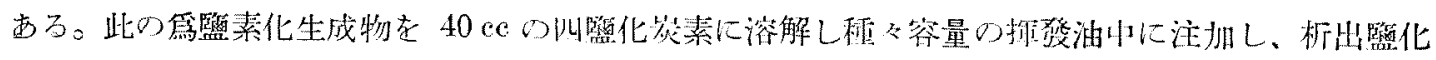

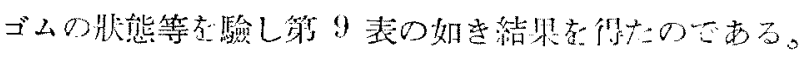

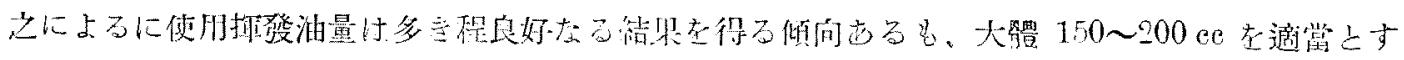
马吼考へら就る。

9 第 9

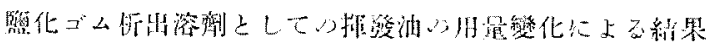

\begin{tabular}{|c|c|c|c|}
\hline 試料番颉 & 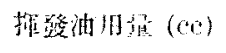 & 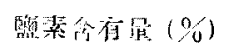 & 栵品い快態 \\
\hline 1 & 50 & 59.90 & 灰白色粒肤 \\
\hline 2 & 100 & 59.85 & $"$ \\
\hline 3 & 150 & 62.82 & 日伯維維邪 \\
\hline+ & 200 & 64.05 & " \\
\hline 5 & 390 & 63.80 & " \\
\hline
\end{tabular}

\section{III 製 造 雳 鮕}

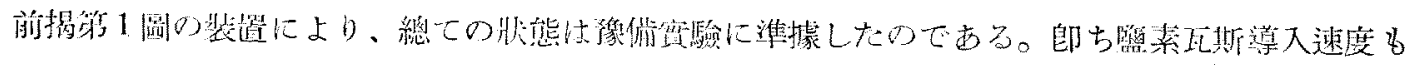

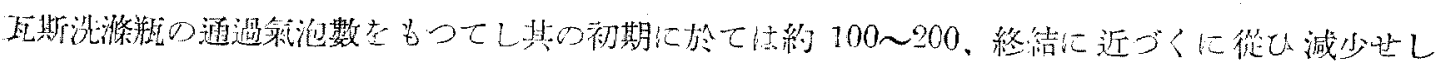

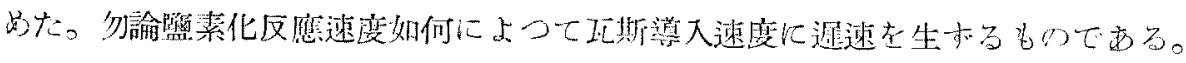

1. 粉末生ゴムの硬化

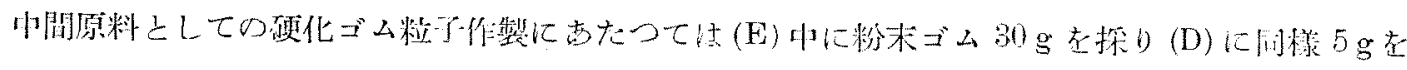

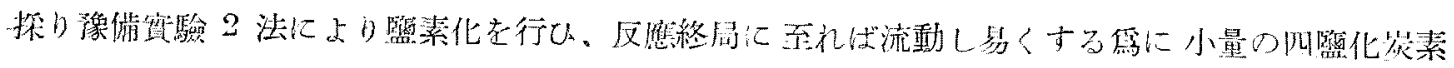




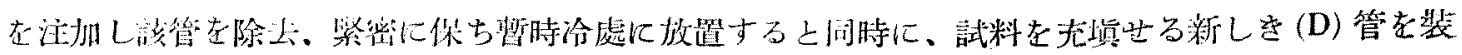

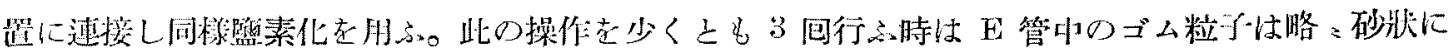

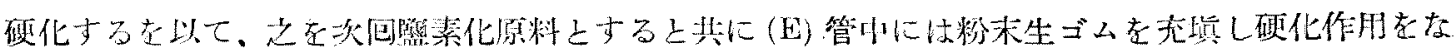
さしさ。

\section{2. 監䇣化行程}

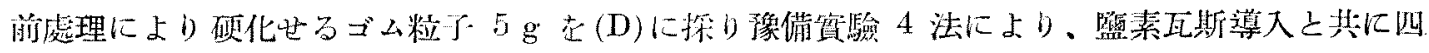

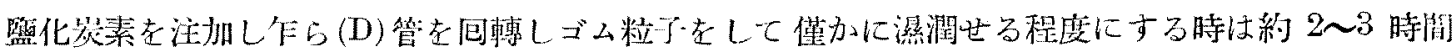

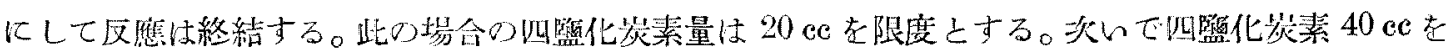

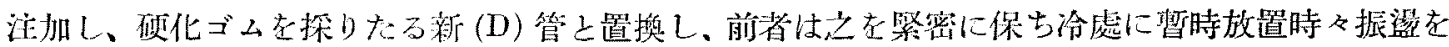

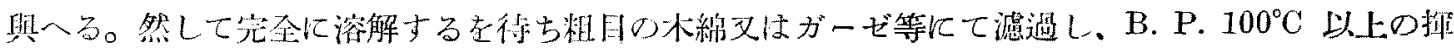
發油 150〜200 ec 中飞瀜下する時は白色塊怳の生成物老析出する。之を㩭挥する時は粒状又は稍粒

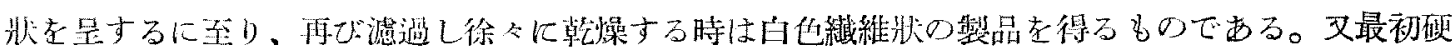

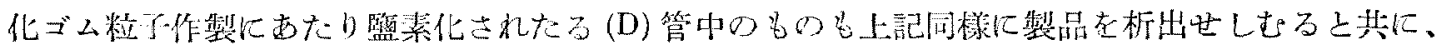

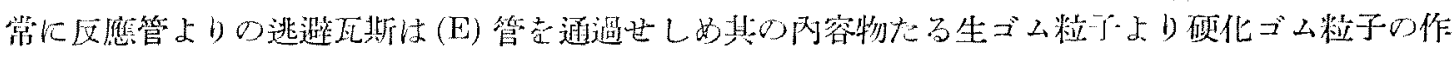
整圭なさしむるのである。

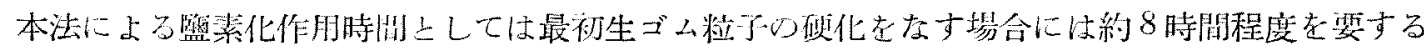

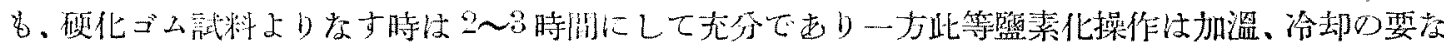

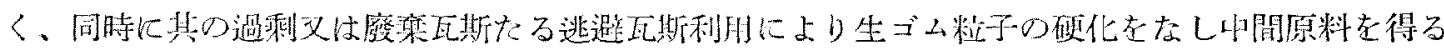

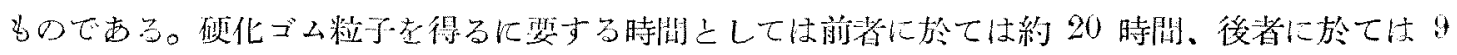

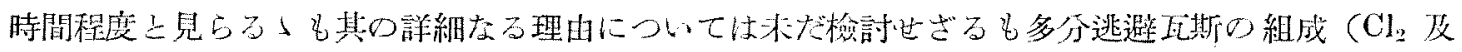
$\mathrm{HCl}$ 其他）に起因名もの之考へられる。

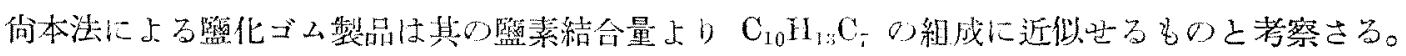

\section{IV 性狀}

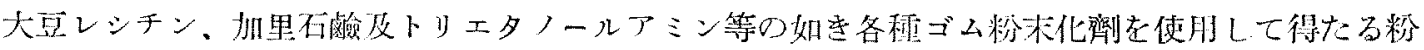

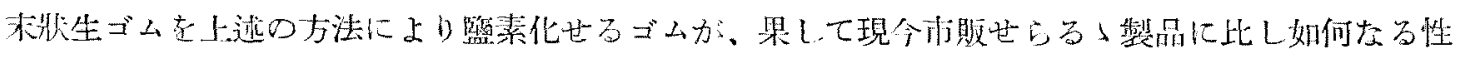

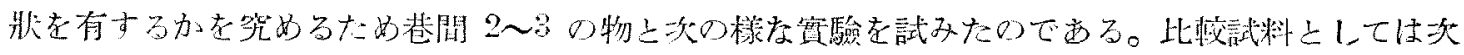
に示す。

\begin{tabular}{|c|c|c|}
\hline \multirow[t]{2}{*}{ 武料委㿠 } & 裴 浩 所 & 佰品名 \\
\hline & 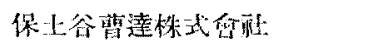 & Aizen \\
\hline & 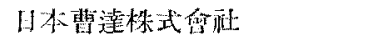 & - \\
\hline (腹序不同) & 積會工業株式筧社 & - \\
\hline & I. G. Farbenind. Akt.-Ges. & Pergut \\
\hline A & 朴赛驗による試作品 & - \\
\hline
\end{tabular}




\section{A. 一般的性 狀}

1. 外觀及粘度

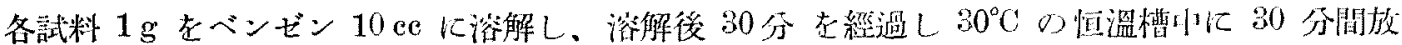

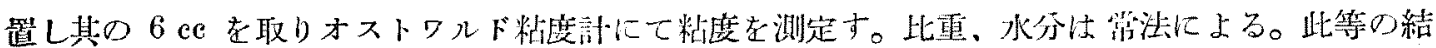
果は第 10 表に示す。

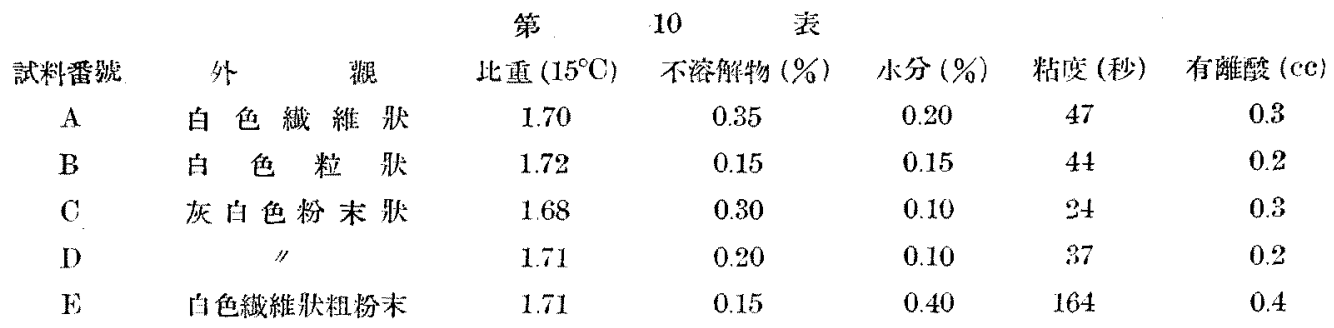

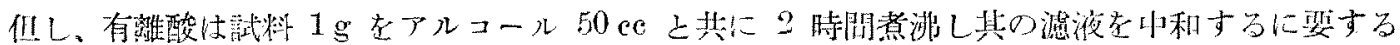
$N / 10 \mathrm{KOH} \varnothing \mathrm{ce}$ 數走示す。

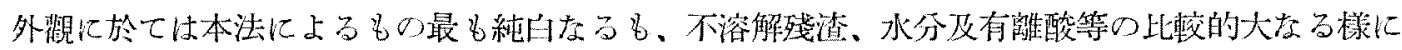
見らる。此等忙生ゴム粉林化に使用する粉末化劑に起因するもの上考察される。

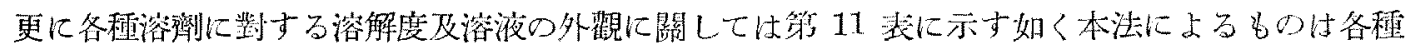
溶劑に對し比較的其の溶解速度綬慢であり、溶液の呈色度は最も小である。

第 11 表

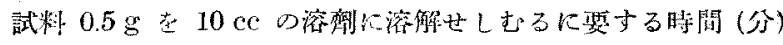

\begin{tabular}{|c|c|c|c|c|c|c|c|c|}
\hline 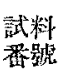 & 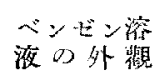 & $\begin{array}{l}\text { ベン } \\
\text { ゼン }\end{array}$ & 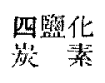 & $\begin{array}{l}\text { タロ } \\
\text { ホルム }\end{array}$ & $\begin{array}{l}\text { 一硫化 } \\
\text { 萩 素 }\end{array}$ & 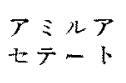 & $\vec{r} ト ン$ & 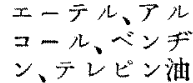 \\
\hline A & 淡黄色透明 & 25 & 85 & 4 & 15 & 4 & 一部涳船 & 不 溶 \\
\hline B & 演色透明 & 93 & 80 & 3 & 10 & 4 & 一部不溶 & $" 1$ \\
\hline $\mathrm{C}$ & 䩤褐色透时 & 6 & 75 & 2 & 5 & 8 & "y & $" 1$ \\
\hline $\mathrm{D}$ & 褐色透时 & 5 & 60 & 1 & 4 & 3 & 一部溶解 & " \\
\hline $\mathrm{E}$ & 琥珀遥明 & 25 & 95 & 4 & 13 & 4 & 一部不溶 & $" 1$ \\
\hline
\end{tabular}

2. 耐 熱 性

各試料 $3 \mathrm{~g}$ をざンゼン 50 ec に溶解し、トリタレジルフォスフェート 0.5 ec t源加し、シャー レに移し厚さ約 $1.5 \mathrm{~mm}$ 直徑約 $75 \mathrm{~mm}$ の皮膜在作製し 100,130 及 $150^{\circ} \mathrm{C}$ 冬 3 時間加桑し其の 第 12 表

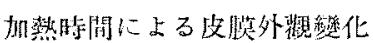

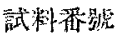
A
B
C
D
E

加 悠 洫 度 (C)

130

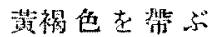

殆儿ど称化なし

黑褐他瑱化于

多儿ど䋨化なし

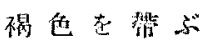

\section{0}

黑裪色在呈す

㫮色星子

㫮褐色是呈 


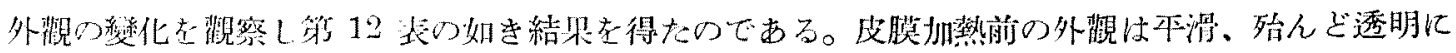

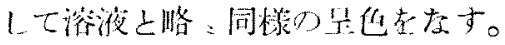

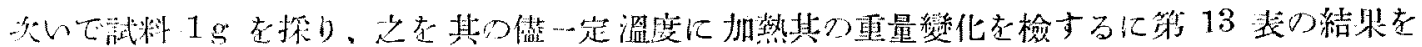
得たのである。

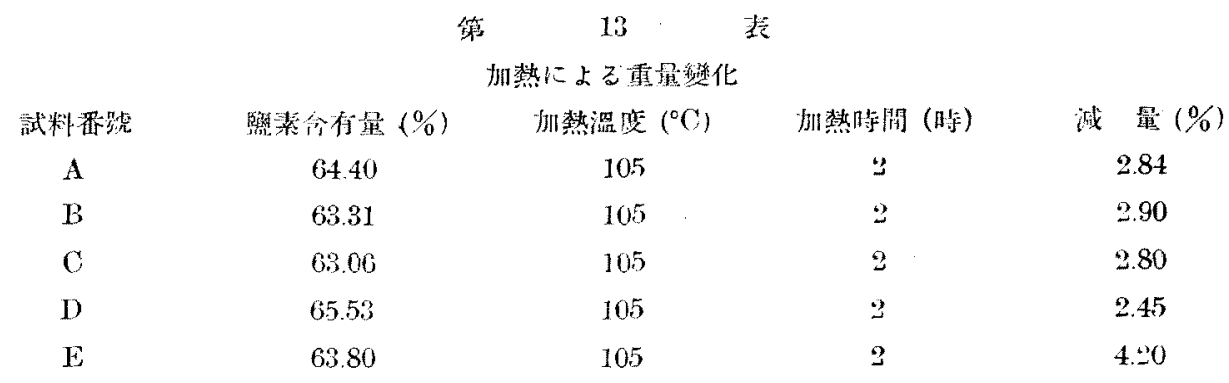

3. 㚣定度

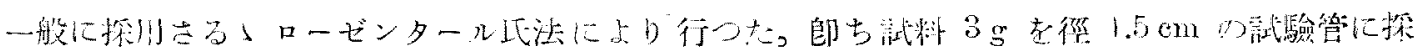

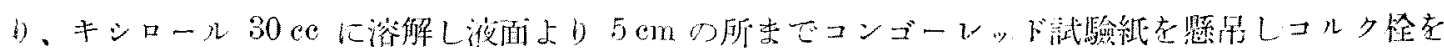

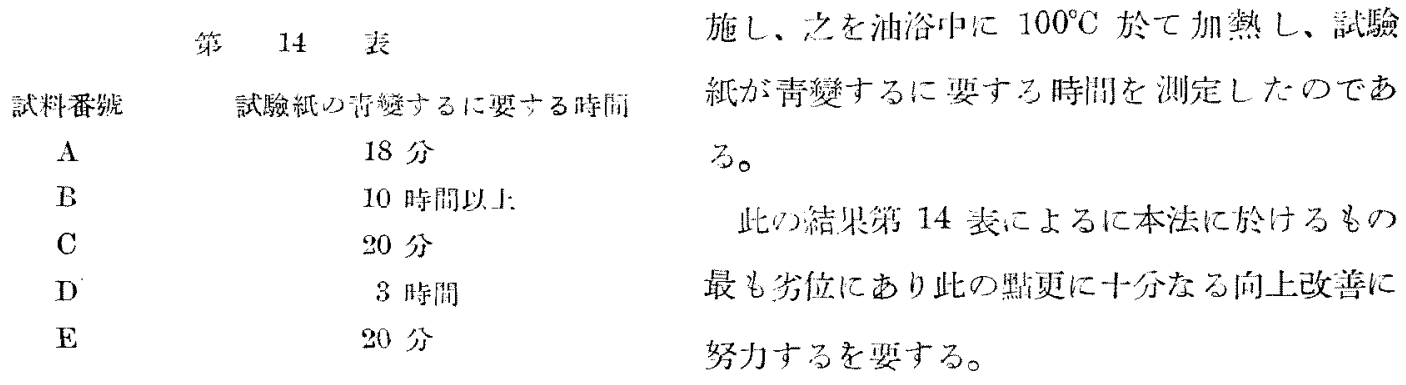

4. 渜化學藥品性

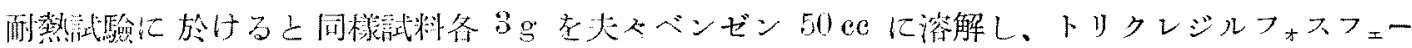

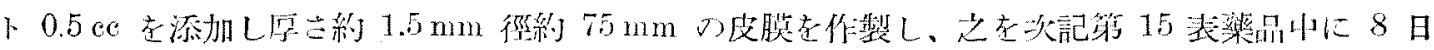

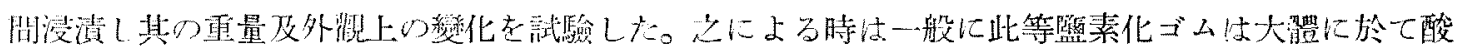

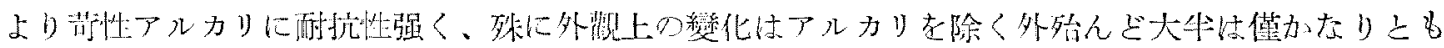

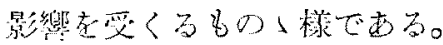

$$
\text { 第 } 15 \text { 表 (其 } 1 \text { ) }
$$

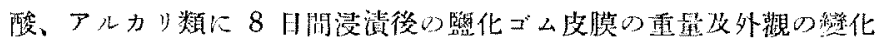

\begin{tabular}{|c|c|c|c|c|c|c|c|c|}
\hline \multirow{2}{*}{ 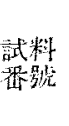 } & \multicolumn{2}{|c|}{$\begin{array}{l}Y \times==J \\
(S .0 .91)\end{array}$} & \multicolumn{2}{|c|}{ 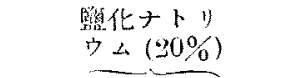 } & \multicolumn{2}{|c|}{ 硫 } & \multicolumn{2}{|c|}{ 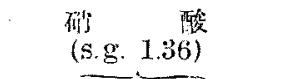 } \\
\hline & 1 & 2 & 1 & 2 & 1 & 2 & 1 & 2 \\
\hline A & +1.31 & 淡㣴裸凹 & -1.21 & $\begin{array}{l}\text { 殆んど瞅 } \\
\text { 化なし }\end{array}$ & -0.40 & 黑䶂色 & -0.41 & 乳白色 \\
\hline B & +0.50 & " & -2.15 & 淡襄色 & +0.68 & 嫼色 & +0.40 & " \\
\hline $\mathrm{C}$ & -0.71 & 淡裼弁 & -2.39 & $\begin{array}{l}\text { 胎儿ど焂 } \\
\text { 化なし }\end{array}$ & -2.14 & 淡慜裼色 & -206 & $"$ \\
\hline D & -1.83 & " & -437 & 淡黃裼色 & -2.92 & 淡褐色 & -3.17 & $" 1$ \\
\hline E & -4.64 & " & $\therefore 7.28$ & 乳白色 & $-4,10$ & 喑褐色 & -8.58 & " \\
\hline
\end{tabular}


(其: $\quad 2$ )
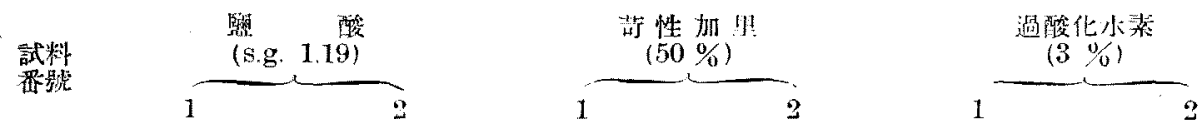

\begin{tabular}{|c|c|c|c|c|c|c|c|}
\hline$A$ & -285 & 谈 & 裸 色 & -1.13 & 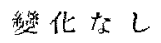 & -1.81 & 私 白 裮 \\
\hline B & +207 & & $" \prime$ & -1.06 & $"$ & -0.75 & $"$ \\
\hline $\mathrm{O}$ & -2.06 & & " & -1.58 & $"$ & -1.41 & 微潯白 \\
\hline D & -4.10 & & $"$ & -1.55 & $" 1$ & -1.38 & 小L \\
\hline$T$ & -4.30 & 恹 & 色 & -8.80 & " & -5.90 & 徼輩白 \\
\hline
\end{tabular}

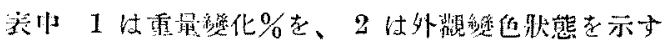

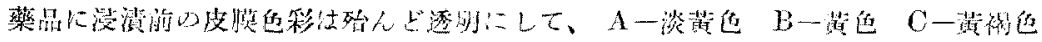

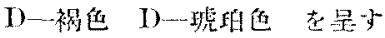

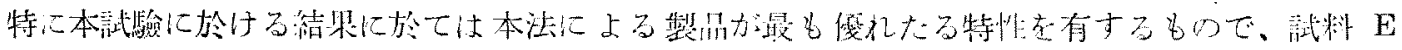
快其の势位にあるものである。

B. 電乐的性状

1. 電莱絽粉性

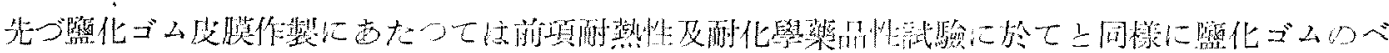

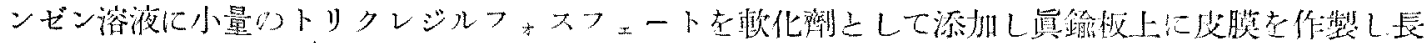

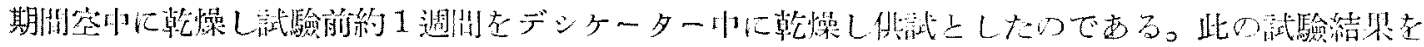
舉ぐるに第 16 及 17 羕に示す通口でする。

\begin{tabular}{|c|c|c|c|c|c|c|c|}
\hline & & & 第 & & 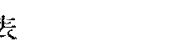 & & \\
\hline 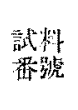 & $\begin{array}{l}\text { 容皘国有抵抗 } \\
\text { D. C. 300V) } \\
(\text { ohm-cm) }\end{array}$ & $\begin{array}{l}\text { 万流 } \\
(1,00000)\end{array}$ & $\begin{array}{c}\text { 誘電䕓 } \\
(\mathrm{K})\end{array}$ & $\begin{array}{l}\text { 試粘 } \\
\text { 涹號 }\end{array}$ & 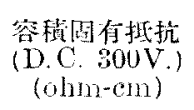 & $\begin{array}{l}\text { 力 } \\
(\tan \delta) \\
(1,000 \mathrm{r})\end{array}$ & $\begin{array}{c}\text { 誘洸掉 } \\
(\mathrm{K})\end{array}$ \\
\hline A & $19.00 \times 10^{15}$ & 0.00543 & 347 & D & $3.04 \times 10^{15}$ & 0.00316 & 2.66 \\
\hline B & $3.60 \times 10^{14}$ & 0.00982 & 2.90 & $\mathrm{E}$ & & 0.00438 & \\
\hline $\mathrm{C}$ & $5.30 \times 10^{13}$ & 0.00893 & 3.00 & & & & \\
\hline
\end{tabular}

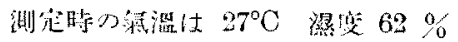

․ 絕 粉 耐 才

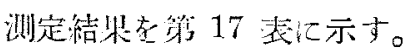

第 17 表

\begin{tabular}{|c|c|c|c|c|c|c|c|}
\hline $\begin{array}{l}\text { 試料 } \\
\text { 涹滰 }\end{array}$ & 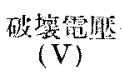 & $\begin{array}{c}\text { 度盟》曆当 } \\
(\mathrm{mm})\end{array}$ & 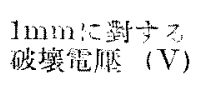 & 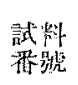 & 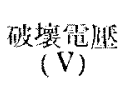 & $\begin{array}{c}\text { 皮焸心愿さ } \\
(\mathrm{mm})\end{array}$ & 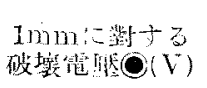 \\
\hline \multirow{5}{*}{$A$} & 2,400 & 0.19 & \multirow{5}{*}{12,817} & \multirow{5}{*}{ B } & 4,400 & 0.27 & \multirow{5}{*}{21,608} \\
\hline & 2,800 & 0.20 & & & 1,300 & 0.28 & \\
\hline & 1,200 & 0.11 & & & 6,400 & 0.24 & \\
\hline & \multirow[t]{2}{*}{2,300} & \multirow[t]{2}{*}{0.17} & & & 7,800 & 0.24 & \\
\hline & & & & & 5,600 & 0.21 & \\
\hline
\end{tabular}




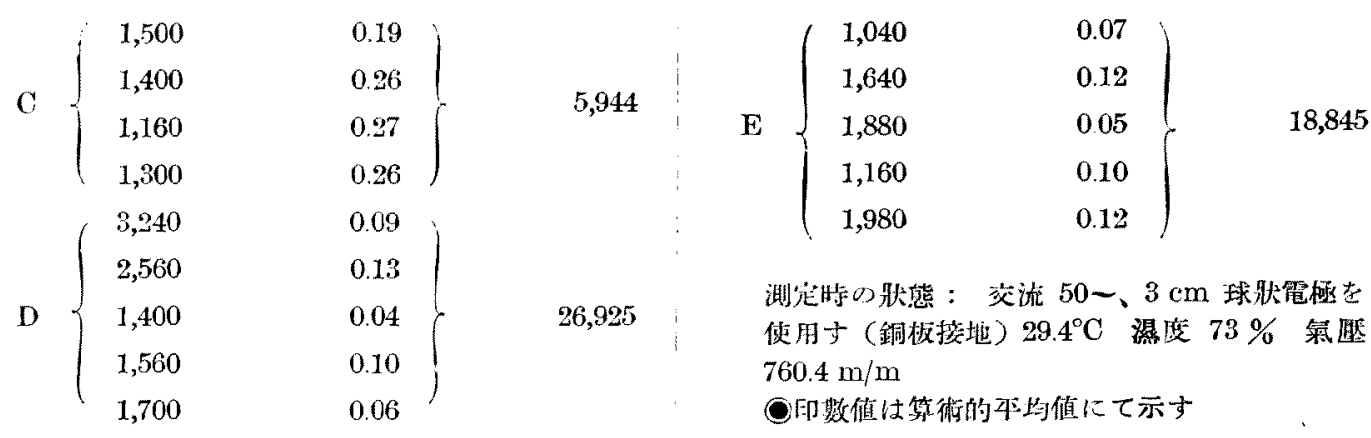

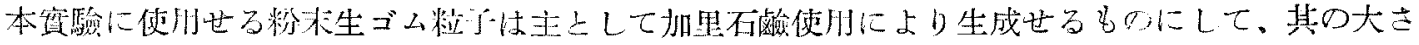

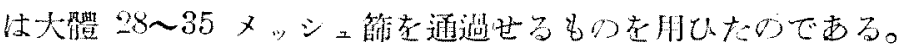

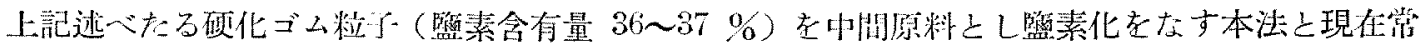

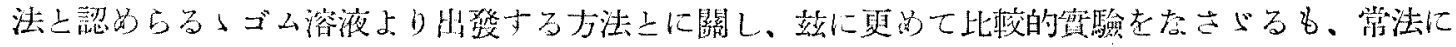

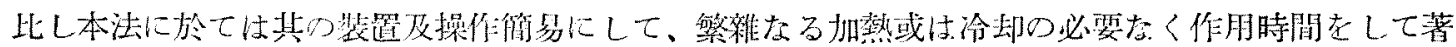

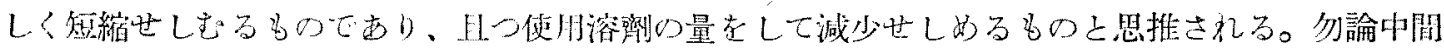

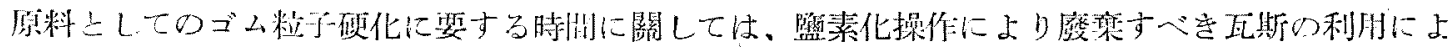

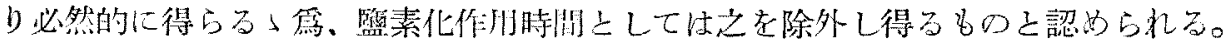

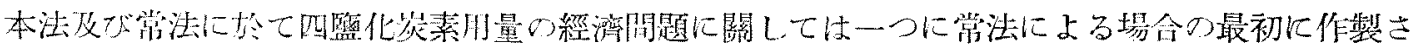

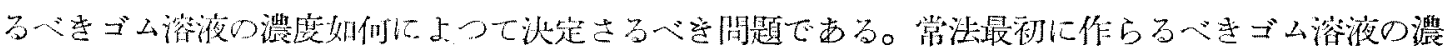

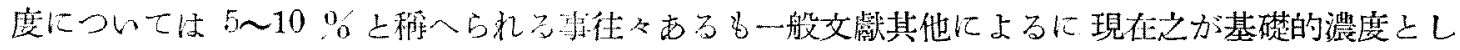
ては 3〜5\%溶液在以て努棠上認められる。

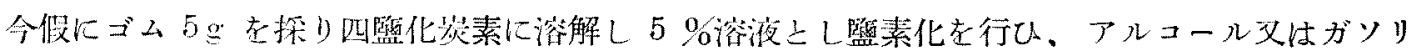

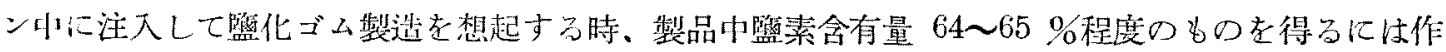

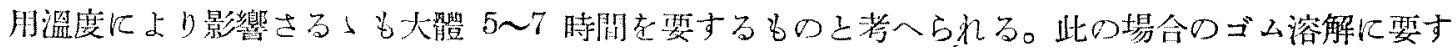

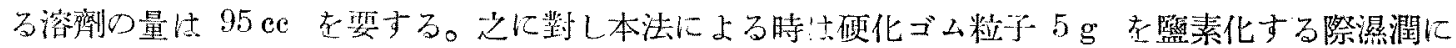

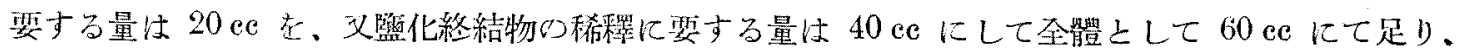

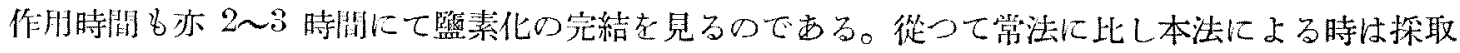

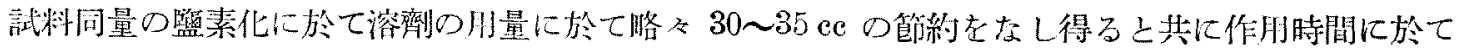
も亦 $1 / 2$ 程度に短緶し得るものである。

次いでローゼンタール安定度試驗に於て本法による試作品の著しく劣位にある默に關してて檢討す るに、中間原料たる硬化ゴム粒于製作にあたり監化物以外に辟化水素の作用により監酸ゴムに類似

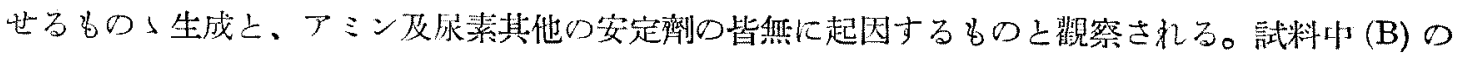




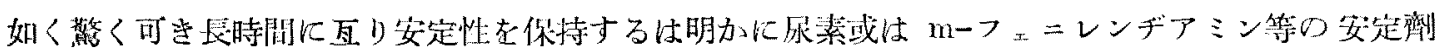
の添加されるる事老肯首出來るのである。

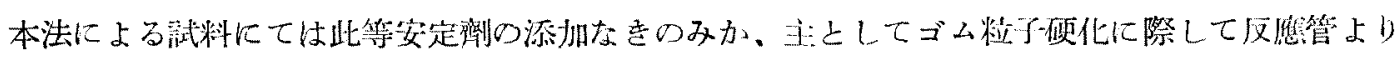

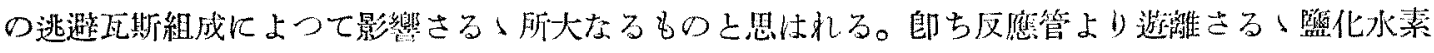

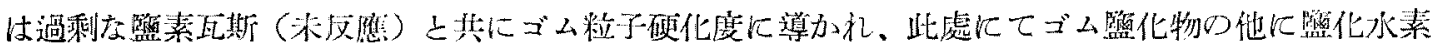

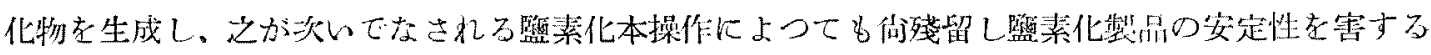

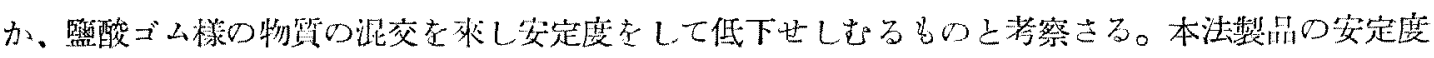

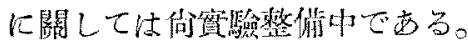

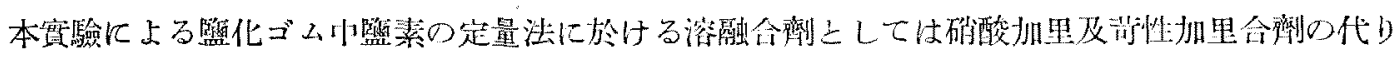

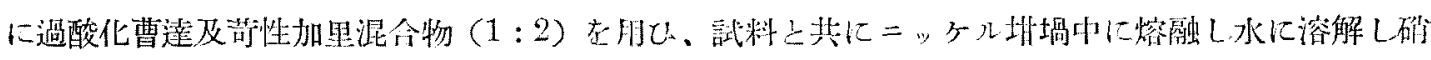

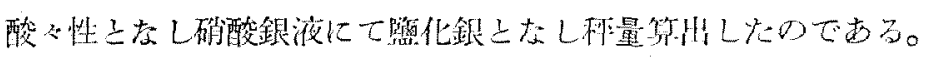

\section{VI 總括}

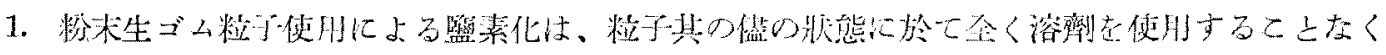

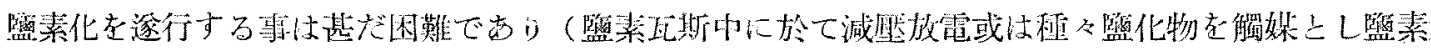

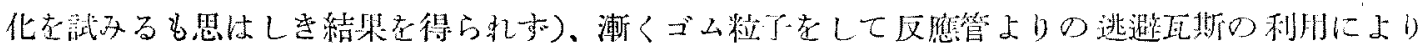

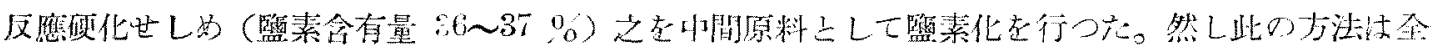

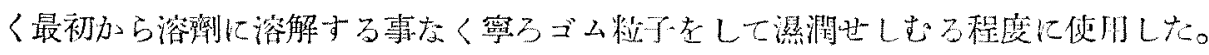

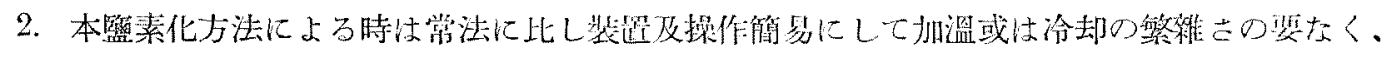

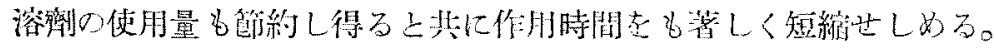

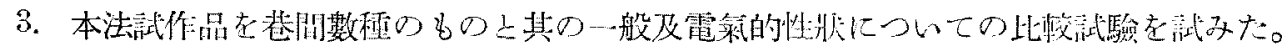

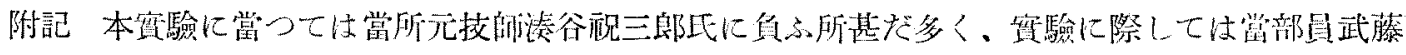

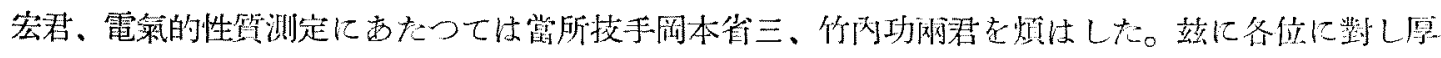
く竘意在表す。 